\title{
Coronavirus Disease 2019 (COVID-19): Its Ramifications on the Economy and Future Perspectives-A Review
}

\author{
Daniel Ofori ${ }^{1}$, George Asumadu2*, \\ Isaac Mensah ${ }^{3}$, Bright Amponsem ${ }^{3}$ \\ ${ }^{1}$ Department of Entrepreneurship and Finance, Kumasi Technical University, Kumasi, Ghana \\ ${ }^{2}$ Department of Accountancy and Accounting Information Systems, Kumasi Technical University, Kumasi, Ghana \\ ${ }^{3}$ Department of Chemical Engineering, Kumasi Technical University, Kumasi, Ghana \\ Email: ^gasumadu@gmail.com
}

How to cite this paper: Ofori, D., Asumadu, G., Mensah, I., \& Amponsem, B. (2021). Coronavirus Disease 2019 (COVID-19): Its Ramifications on the Economy and Future Perspectives-A Review. Modern Economy, 12, 944-959.

https://doi.org/10.4236/me.2021.125048

Received: April 1, 2021

Accepted: May 15, 2021

Published: May 18, 2021

Copyright $\odot 2021$ by author(s) and Scientific Research Publishing Inc. This work is licensed under the Creative Commons Attribution International License (CC BY 4.0).

http://creativecommons.org/licenses/by/4.0/

\begin{abstract}
The purpose of this paper is to review the existing literature and updates on positive and negative impacts of the trend of the COVID-19 pandemic on the economy, since no permanent solution has been found. Data drawn from various sources in the form of daily briefings of health and economic experts, bulletins and reports from UN agencies and other agencies were utilised. The study serves as a contribution to insight to enable policy makers to brace for the unexpected as the world is unfolding to unprecedented in the new millennial. It was found that measures such as lockdown, travel bans, closure of schools, churches and Mosques, restaurants, and bars were adopted to control the disease in the economy, as adopted in other parts of the world. The disease harmed the economies enormously, including trade, investments, and the fall in oil prices. The use of different types of nose masks, veronica buckets and sanitizers has been found in the Ghanaian market. Nonetheless, the number of cases is still on the rise due to improper usage and contamination of nose masks by people and the discovery of new variants of COVID-19 in other places has also exacerbated the problem. Currently, there is an approved vaccine to curb the virus in the country, but only a few selected categories of citizens have received first jab and many people do not follow the laid down protocols-a concern to surmount the spread of the pandemic in the country amidst the fear of a third variant of the virus emerging.
\end{abstract}

\section{Keywords}

COVID-19, Coronaviruses, Economy, Non-Medical Nose Mask, Impact, Growth, Perspectives 


\section{Introduction}

Coronaviruses are a cluster of viruses capable of producing severe acute respiratory illnesses. Examples include Severe Acute Respiratory Syndrome Coronavirus (SARS-CoV), Middle East Respiratory Syndrome Coronavirus (MERS-CoV), and Coronavirus Disease 2019 (COVID-19) (Parolin et al., 2020; Lei et al., 2018; Minnesota Department of Health, 2020). The most common signs of coronavirus infected coronaviruses include fever, dry cough, dyspnea, fatigue, myalgia, anorexia, and chest pain. Headache, sore throat, rhinorrhea, dizziness, abdominal pain, diarrhea, nausea, vomiting, confusion, and chest pain are among the less common (Ahmed, 2020; Huang et al., 2020; Wang et al., 2020; Zhu et al., 2020).

According to the (World Health Organization (WHO), 2020a; Soewarno, 2020), coronaviruses can infect a wide range of animals (including bats, palm civets, and pangolins). The four main types of human coronavirus (HCoV) are HCoV-229E (alpha coronavirus), HCoV-NL63 (alpha coronavirus), HCoV-OC43 (beta coronavirus), and HCoV-HKU1 (beta coronavirus) (Ibid).

In the past two decades, other HCoVs such as SARS-CoV-1, MERS-CoV, and recently SARS-CoV-2, all beta coronaviruses, have evolved to threaten human existence. The SARS outbreak emerged between 2002-2003 season in Guangdong Province, China, which affected 8098 patients and claimed 774 lives. It was later recorded in 29 European, North American, and South American countries. On the other hand, the MERS outbreak emerged in 2012 in Saudi Arabia, spreading to countries such as Germany, the United Kingdom, and Tunisia, with a mortality rate of 34.4\% (Isihak et al., 2020; Ahmed, 2020). According to Dhama et al. (2020), the mortality rate of SARS-CoV-2 cannot be compared to that of SARS-CoV-1 and MERS-CoV; however, the former has caused more deaths than the two combined.

COVID-19 was initially named by the WHO as a novel coronavirus-infected pneumonia (NCIP) (Ahmad et al., 2020). On January 7, 2020, NCIP was changed to the 2019 novel coronavirus (2019 n-CoV) by the WHO (Hui et al., 2020). On February 11, 2020, the causative agent of COVID-19 was found to be closely related to that of SARS; therefore, severe acute respiratory syndrome coronavirus 2 (SARS-CoV-2) was identified by the International Committee on Taxonomy of Viruses. It was on the same day that the WHO officially announced in a tweet that the new name for the virus will be recognized as COVID-19 (Gorbalenya et al., 2020; WHO, 2020b).

To date, the etiology of COVID-19 remains unclear. Nonetheless, it was reported that in early December 2019, a considerable number of patients developed pneumonia in Wuhan City, Hubei Province, China. This zoonotic disease is closely linked to the Huanan seafood wholesale market, with the perception that SARS-CoV-2 is transmitted from animals to humans (Qu et al., 2020). Buttressing this is the fact that the majority of patients who first tested positive have had exposure there (Helmy et al., 2020). On the other hand, some researchers have found that a more recent diagnosis is not connected with the Huanan 
Market and concluded that human-human transmission is, therefore, possible (Unhale et al., 2020; Yu et al., 2020; Cohen, 2020). According to the WHO, the current outbreak is a pandemic. As of March 2020, the disease has proliferated across the globe in six continents, affecting almost 199 countries (Larbi-Odam et al., 2020; Naser et al., 2020).

COVID-19 is primarily transmitted between humans via respiratory/aerosol droplets and is in close contact with either symptomatic or asymptomatic patients. Other ways through which transmission may occur include fomites (surface contamination) and fecal-oral routes (Ong et al., 2020; Zhou et al., 2020; Li et al., 2020). At the end of the third week in January 2021, the global confirmed COVID-19 cases stood at 99,727,853 with 2,137,670 deaths (ECDC, 2021). With this figure, the mortality and recovery rates are $4.48 \%$ and $58.26 \%$ respectively. Meanwhile, in Ghana, the number of confirmed cases on the same date is 23,463 , with 18,622 recoveries and 129 deaths (Ghana Health Service, 2020). This corresponds to recovery and mortality rates of $79.37 \%$ and $0.55 \%$, respectively.

To curb the spread of the virus, interventions such as lockdown, closure of bars, schools, restaurants, churches and mosques, international and domestic travel bans, and personal hygiene, such as wearing of face masks, handwashing with soap, and the use of sanitizers were imposed by governments and authorities on the citizenry. The repercussions of the above-mentioned interventions have had an enormous impact on the economy such as trade, investments, oil prices, etc. all being affected (Ozili \& Arun, 2020).

This is projected to escalate if the outbreak of the COVID-19 outbreak is prolonged. For instance, according to Deloitte, the estimated global GDP growth of $3.3 \%$ is reduced to approximately $2.9 \%$, whereas that of Africa is expected to reduce to $1.8 \%$ from the estimated $3.2 \%$ by 2020 . In Ghana, the estimated GDP growth for 2020 was $6.8 \%$; however, this figure is expected to fall to $2.6 \%$ due to COVID-19. On the flip side, the impact of COVID-19 has brought inventions and innovations to the Ghanaian business sector. Notable among them is the development of a solar-powered hand-washing sink and a COVID-19 prevention electronic bucket (Modernghana, 2020). The production of hand sanitizers and nose/face masks has also led to the creation of employment among youth. The purpose of this paper is to review the existing literature and updates on the positive and negative impacts of the trend of the disease on the economy, since no permanent solution has been found. The study serves as a contribution to insight to enable policy makers to brace for the unexpected as the world is unfolding to unprecedented catastrophe in the new millennial.

The study is made up of eight (8) sections, namely introduction, methodology, impact on global economy, impact on African economy, impact on Ghanaian economy, discussion, conclusion and limitation and future studies.

\section{Methodology}

Several articles found in the literature on COVID-19 were reviewed in tandem 
with updates from sources such as the daily and periodic briefings of the National Committee on the pandemic, the World Health Organization, data from the World and Africa Outlook, Ministry of Finance and Economic Planning of Ghana, and individual articles were combed as a source of information to discuss the economic impact and the trend of the disease. The Authors also made use of the mid-year review of the 2020 Budget as well as the 2021 Budget Statement of the Republic of Ghana, presented at the Parliament by the Majority leader on March 12, 2021. In particular, the research design is based on desk research, as this is a review paper and for that matter, the secondary source of materials was the epitome of the study. The essence of using desk research methodology stems from the fact that the COVID-19 pandemic is still evolving and many communities experiencing different cases of its spread due to the behavioral characteristics of the community. Expert advice and briefings are received intermittently through various communication media-online, social media, television, daily newspapers, and news bulletins. This information was synthesized by using meta-narratives. This is in line with the semi-systematic review design advocated by Wong et al. (2013), as described by Snyder (2019). The strategy of the study was to look into the plethora of world trends of socio-economic impact of COVID-19 as the world, Africa and Ghana in particular adopted unprecedented measures to face-off the spread of the pandemic. The data area looks at the impact of COVID-19 on the geographical areas below of the effects of the pandemic on the economies:

\section{Impact on the Global Economy}

Globally, due to the developmental growth of science and technology, it appears the economic activities of the world are closely integrated. Thus, if anything good happens in country " $A$ ", it would have a medium to high effect on other countries. The emergence of the spread of coronavirus in Asia, China has been attested to this scenario. The United States of America is the largest economy in the world, second to China, which is worth $\$ 13.6$ trillion, about $16 \%$ of the total World's GDP (Mahmud, 2020). Many countries across the world import goods from China for their economic activities and because China is the first country the COVID-19 pandemic was first detected, its lockdown, including companies, has affected countries that depend on their goods and services. The worst time was when various countries began to exercise lockdowns and even closed their borders as the best option to control the spread of the virus. The virus within the first half of 2020 has caused numerous deaths and sufferings among men, women, and children all over the world, causing a halt to global supply and demand chains (Abinraj, 2020). The global economic growth in 2019 was $2.9 \%$ and was projected to be $3.3 \%$ by the end of 2020 , but the spread of coronaviruses has shrunk the situation of the world economy within the first half of 2020. This has caused the annual global GDP growth to drop to $2.4 \%$ in 2020 , with a growth rate projected negatively in the first quarter of the year (Kumar, 2020). Accord- 
ing to the Asian Development Bank (ADB), global trade has been hampered by lock down restrictions to the tune of USD dollars 1.7 trillion to US dollars 2.6 trillion (ADB Briefs No. 133, May 2020). The real impact of the virus can be fully estimated when the cure for the virus is fully discovered; otherwise, the untested assumptions for current economic growth projections cannot save the world economy (Di Gennaro et al., 2020).

In estimating April 2020 world economic outlook projections (see Figure 1), the assumptions factored depend on the depth of the contraction in the second quarter of 2020, as well as the magnitude and persistence of the adverse shock. The forecast depends on several uncertain factors, including

1) The required end time of the pandemic and lockdowns

2) Social distancing

3) Business closures and workers exiting the workforce

4) The impact of changes to strengthen workplace safety

5) Global supply chains

These uncertain assumptions can recover the world economy as long as there is a cure, but can also be worse if the pandemic persists for a longer period. Again, according to Figure 1, the global GDP growth is projected to be $-4.9 \%$. At baseline, global economic activity is expected to decrease in the second quarter of 2020, recovering thereafter. These projections are only possible if the assumptions taken for the assessment do not change; thus, when there is a cure for

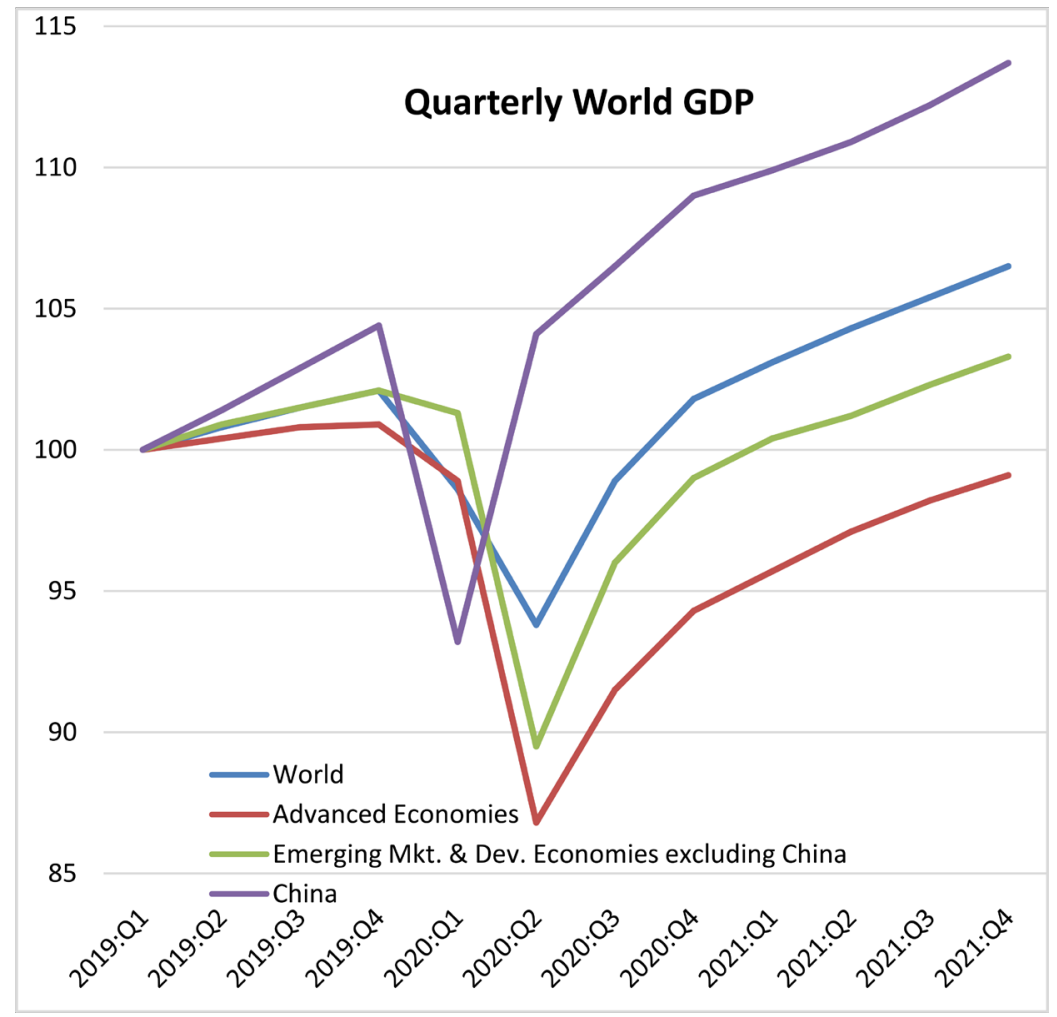

Source: IMF staff estimates and projections, June 2020.

Figure 1. Quarterly world GDP. 
the cause. In 2021, growth is projected to increase to 5.4 percent and $0.4 \%$ lower than the April forecast. Consumption is projected to gradually strengthen the next year, and investment is expected to increase. The global GDP for 2021 is forecasted to exceed the 2019 level. The growth rate for emerging markets and developing economies is projected to be $-3.0 \%$ in 2020, which is $2 \%$ below the April 2020 world economic outlook forecast. The growth rate among low-income developing countries is projected to be $-1.0 \%$ in 2020 and $1.4 \%$ below the April 2020 world economic outlook forecast. In low-income developing countries, the projection is $2.2 \%$ by 2020 (Tralac's Daily News Selection, 2020; IMF, 2020).

\section{Impact on Africa Economy}

The African Economic Outlook (see Figure 2) projected the African economic growth rate to be $3.4 \%$ for both 2018 and 2019. This growth rate was stable between these two years, but was lower for 2010-2015. African socio-economic growth was expected to be sustained after 2010, but it failed because there was a high dependency ratio on foreign businesses and services. This has been a major challenge in Africa.

The growth rate projections for 2020 and 2021 were $3.9 \%$ and $4.1 \%$, respectively. The 2019-2021 growth projections can be assumed to indicate that Africa's economy is growing, but the impact of the pandemic can alter this scenario. East Africa maintained its lead as the continent's fastest-growing region, with an average growth of 5.0\% in 2019 (Njugunah, 2020). North Africa had the second highest share (4.1\%). West Africa's growth rose to $3.7 \%$ in 2019, from $3.4 \%$ in the previous year. Central Africa is estimated to have grown by $3.2 \%$ in 2019 , from $2.7 \%$ in the previous year. Southern Africa's growth slowed from $1.2 \%$ to $0.7 \%$ (Ibid).

Some of the few main areas affected are tourism, air transport, and the oil

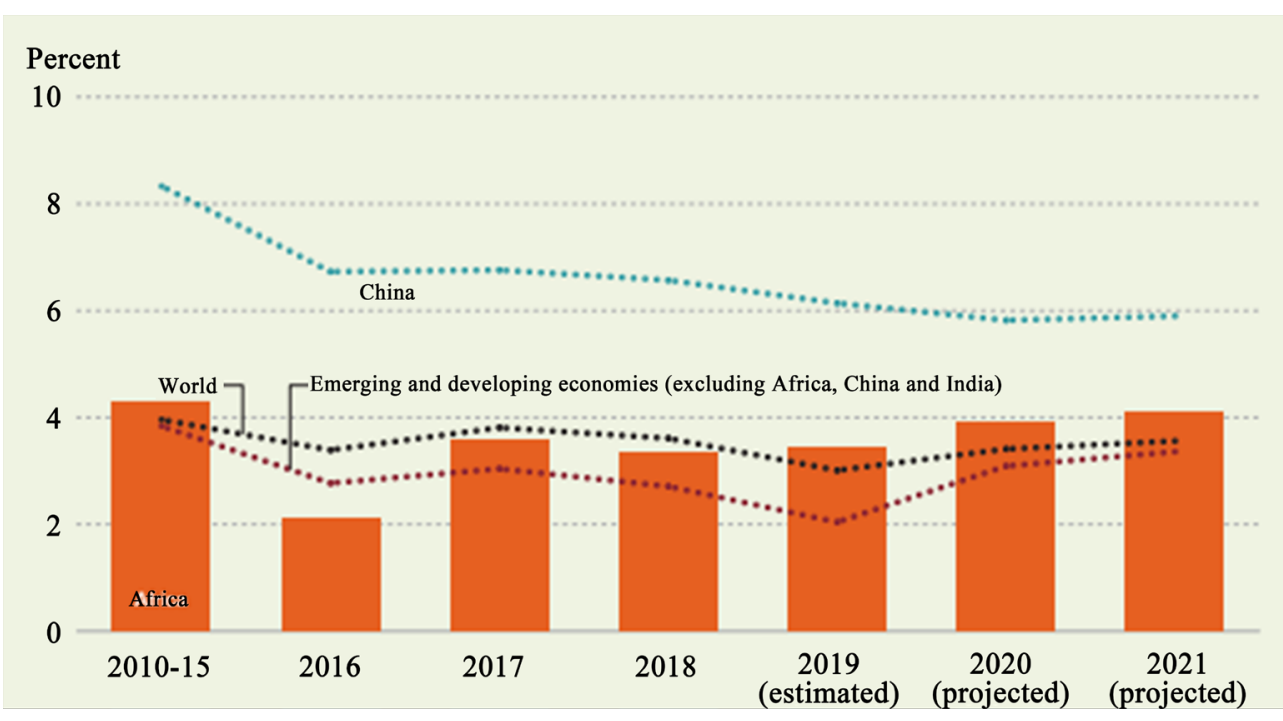

Figure 2. Africa's GDP growth. Source: African Development Bank and IMF World Economic Outlook. 
sector. These sectors were severely affected during the lockdown, as the movement of people, goods and services slowed down. The COVID-19 pandemic has spread across almost all parts of Africa and its effect continues to worsen daily. The fall of the African economy can be caused by a fall in commodity prices, fiscal revenues and the enforcement of travel and social restrictions in many African countries (OECD, 2020). African countries' exports and imports are projected to drop by at least 35\% from the level reached in 2019 (Ibid; icsb.org) (The Zimbabwe Independent, 2020). Thus, the loss in value was estimated to be $\$ 270$ billion US dollars (The Zimbabwe Independent, 2020). Fighting against the spread of the virus and medical treatment will lead to an increase in public spending in Africa, estimated to be at least 130 billion (icsb.org, 2020; Anele, 2020; African Economic Outlook, 2020).

The West Africa sub-region, with its political and economic block, the Economic Community of West African States (ECOWAS), is heavily affected by the COVID-19 pandemic. The region's economy contracted by 2.5\% (Ministry of Finance and Economic Planning, 2021).

\section{Impact on Ghana Economy}

The government of Ghana on March 30, 2020, initially laid out key measures to combat the pandemic by limiting and stopping the importation of the virus, containing its spread, providing adequate care for the sick, limiting the impact of the virus on social and economic life, inspiring the expansion of our domestic capability and deepening our self-reliance (Ayadi et al., 2020). Although the key measures adopted have been scientifically proven to be used to curb the pandemic, the cases are worsening daily. This is not only in Ghana, but globally, because there is no cure.

The impact of the pandemic affected the GDP growth of Ghana, significant shortfalls in petroleum revenues, shortfalls in import duties, shortfalls in tax revenues, and increased health expenditures (Ofori-Atta, 2020). It was estimated that the three-week lockdown in Greater Accra and Greater Kumasi led to a decrease in GDP by $27.90 \%$ and over 3 million fell into the poverty bracket during the same period (Amewu et al., 2020). The Ghanaian economy is dominated by small- and medium-sized enterprises and the markets are dominated by informal sectors. That is, most people living in urban areas trade in congested city markets and are hardly hit by the lockdown (Asante \& Mills, 2020). COVID-19 has affected Ghana economically and its social dimensions. The pandemic has affected production, trade, and investment in Ghana, just as it has ravaged economic and social activities in the rest of the world, especially in China, Europe, and the United States (Factcheckghana, 2020). Global commodity (crude oil, gold, and cocoa) prices, tourist flows, fiscal stance, and human life, especially the health and life of the most vulnerable (Ibid). The indirect route is through the slowing of global economic growth, supply chain disruptions, and, by extension, the negative impact on Ghana's growth. Ghana's economic impact can be worse if the dependency on imports is not resolved in times like this, since the export- 
ing country can decide to close its borders at any time. The measures for controlling diseases by the Ghana government are not so far from the WHO measures to combat the pandemic (Ibid).

The Government of Ghana has taken strides to alleviate the impact of the COVID-19 pandemic on the economy through both monetary and fiscal policies. The Bank of Ghana cut the policy rate by 150 basis points to $14.5 \%$ and reduced the primary reserve requirement from $10 \%$ to $8 \%$ (PwC, 2020; Ministry of Finance and Economic Planning, 2020). The Government also arranged with her creditors, including Bank of Ghana to defer interest payments on non-marketable instruments, estimated at about 1.2 billion Ghana Cedis beyond $2022 \mathrm{ibid}$.

As a result of the COVID-19 pandemic, the Government of Ghana revised her real GDP growth downward from $6.8 \%$ to $0.9 \%$ due to the mid-year review of the 2020 budget and achieved only $0.2 \%$ real GDP growth, as indicated in Table 1.

The impact of COVID-19 has also been positive for boosting certain businesses. Businesses such as nose masks and hand sanitizers have shifted to new opportunities in Ghana. Currently, there are different types of nose masks or brands of sanitizers that are readily available for people to buy and use. The COVID-19 recovery pathway will not simply ease supply disruptions; it has created new opportunities for doing things differently. For example, schools, churches, shops, and other businesses are strengthening their online systems to provide another means of serving their functions to the people of Ghana (Mugisha, 2020; Ofori-Atta, 2020). The government also instituted COVID-19 Alleviation and Revitalization of Enterprise Support Programme, dubbed Ghana Cares. The programme aims to mitigate the impact of the pandemic on people and businesses, as well as to provide a framework for the country to embark on industrialization drive (Ministry of Finance and Economic Planning, 2021).

\section{Discussion}

The COVID-19 pandemic has affected every facet of the economy and household

Table 1. 2020 revised medium-term macro-fiscal targets and 2021 budget projections.

\begin{tabular}{ccccccc}
\hline & & \multicolumn{3}{c}{2020} & 2021 & 2022 \\
\cline { 3 - 7 } N/n & Item & $\begin{array}{c}\text { Budget } \\
\text { Projections }\end{array}$ & $\begin{array}{c}\text { Mid-year } \\
\text { Revised } \\
\text { Projections }\end{array}$ & Achieved & Budget & Projections \\
\hline 1. & Real GDP Growth (\%) & 6.8 & 0.9 & 0.2 & 5.0 & 5.0 \\
2. & Non-Oil GDP Growth (\%) & 6.7 & 1.6 & 0.4 & 6.7 & 4.7 \\
3. & End-Period Inflation (\%) & 8.0 & 11.1 & 10.4 & $8 \pm 2$ & $8 \pm 2$ \\
4. & Fiscal Balance (\%) & $(4.7)$ & $(11.4)$ & $(11.7)$ & $(9.5)$ & $(7.5)$ \\
5. & Primary Balance (\%) & 0.7 & $(4.6)$ & $(5.3)$ & $(1.3)$ & 0.2 \\
6. & Gross International & $\geq 3.5$ & $\geq 4.0$ & $\geq 4.1$ & $\geq 4.0$ & $\geq 4.5$ \\
\hline
\end{tabular}

Source: Extract from Ministry of Finance (MoF) Ghana: Year 2021 Budget. 
productivity is at its lowest level due to the shrinking of business activities. Vulnerability of small to medium enterprises has a direct effect on the household income generation.

The face mask contributes to a reduction in the spread of infections in the community. According to ECDC, this is done by minimizing the excretion of respiratory droplets from infected individuals who may not even know that they are infected (asymptomatic) and before they develop any symptoms (ECDC, 2020). The types of face masks commonly available in Ghana include medical face masks, non-medical face masks, and filtering face piece. Medical face masks were used as source controls for the symptomatic patients. The spread of respiratory droplets is caused by coughing or sneezing. Medical masks as source control have been shown to decrease the release of respiratory droplets (Leung et al., 2020). It is used to prevent the spread of tuberculosis (Dharmadhikari et al., 2012) and influenza (Macintyre et al., 2015). Medical masks satisfy European Standard EN 14683:2014 (ECDC, 2020). Non-medical face masks (or 'community' masks) were made from cloth and other textiles/materials. They are easily made, washed, reused, and not standardized. It is not recommended for use by healthcare professionals. A respirator or filtering face piece (FFP) is designed to protect the wearer from exposure to airborne contaminants. Respirators are mainly used by healthcare workers to protect themselves (Version 10,2020). It is typically used, especially during aerosol-generating procedures. Respirators satisfy European Standard EN 149:2001+A1:2009. It has been proven that persons with mild or no symptoms can contribute to the spread of COVID-19 (Rothe et al., 2020; Ganyani et al., 2020; Zou et al., 2020; Nishiura et al., 2020; To et al., 2020; Wei et al., 2020; WHO, 2019). There is conflicting evidence on the protective effect of medical face masks for the wearer of influenza (Cheng et al., 2010; Aiello et al., 2010; Larson et al., 2010). Because there is a lack of evidence, it has not been recommended that people who are not sick or health workers should wear a mask to prevent the spread of influenza or COVID-19. However, the WHO recommends the use of masks to justify the risk and impact of epidemic and pandemic influenza (WHO, 2019). It must be understood that decisions were based on studies of influenza and other coronaviruses. However, this may not be directly applicable to the COVID-19. There is no evidence that face masks or shields are effective against respiratory infections. Generally, the non-medical face mask has been identified to be less efficient in microorganism penetration and source control than the medical mask (2\% - 38\%) (Rengasamy et al., 2010; Davies et al., 2013). For economic activities to go on as normal, the Government Ghana directed that every worker should put on a face mark and organizations should adhere to WHO guidelines, put forth by the National Health Committee on COVID-19. These measures are not different from what is epitomized in (ECDC, 2021) to ensure containment of the pandemic.

Non-medical face masks and face covers are currently used by most Ghanaians because they are easy to produce, wear, and recycle. The most common 
types in towns include textiles, plastic face shields, and medical masks. The textiles face mask business in Ghana is rising every day because the product is affordable and available compared with other types. The question is how effective can local masks be? The health impact of health on users is currently unknown.

The use of face masks may provide a false sense of security, leading to suboptimal physical distancing, poor respiratory etiquette, hand hygiene, and even not staying at home when ill (Sengbeh, 2020). There is a risk that improper removal of the face mask, handling of a contaminated face mask, or an increased tendency to touch the face while wearing a face mask by healthy persons might increase the risk of transmission. Medical face masks are currently in a short supply. Given the current pressure on health systems, healthcare workers' use needs to be prioritized and protected (Ibid).

Since the cases are rising daily, it is possible that masks can cause infection if not properly used. The appropriate use of face masks is a long way to protect people. It is incumbent on civil society to intensify information campaigns for the proper use of face masks. The face mask should completely cover the face from the bridge of the nose to the chin (ECDC, 2021). One has to clean hands with soap and water or an alcohol-based hand sanitizer before putting on and removing the face mask Ibid. When taking off the face mask, remove it from behind and avoid touching the front side. Dispose the face mask safely if it is disposable, wash your hands or apply an alcohol-based hand sanitizer immediately after removing the face mask Ibid. Washable, reusable faces should be washed as soon as possible after each use, using a common detergent at $60^{\circ} \mathrm{C}$ (National Institute for Occupational Safety and Health, 2018).

\section{Conclusion}

It has been observed that the world has been threatened by human coronavirus diseases for the past two decades and therefore, countries should guard themselves against possible catastrophe from the pandemic.

International trade and technology have made the world a global village; therefore, the activities and cultures of other nations should be critically monitored since the economic effects of the virus have been felt by all.

Additionally, the pandemic has brought together the work of policy (law) makers and the scientific community in coming out with approaches for the populace in going about their duties.

In Ghana, although interventions such as the closure of churches, travel bans, spraying of markets, and closure of bars and schools have affected business activities, this has led to the fulfillment of the well-known English language proverb "necessity is the mother of inventions," as most companies and individuals have turned to produce nose masks, hand sanitizers, etc.

The economy should embrace diversification by taking advantage of the African continental free trade area (AfCFTA), and its implementation is out doored to avoid world commodity price volatilities. 
As the virus continues to metamorphose itself into variants, as it has been reported that a third variant has emerged and some countries have decided to go on a lockdown during the Easter holidays, it is premised for every economy to take precaution for any eventuality.

The 2021 budget deficit of $1.3 \%$ of GDP of the Ghanaian government is to help alleviate the plight of the COVID-19 pandemic on the citizenry as well as the small- and medium-sized establishments. Governments are encouraged to pursue economic policies, that would protect lives in the short-run and the economies would bounce in the long run.

In a nutshell, future research work should look at the opportunities brought by the COVID-19 pandemic in the areas of creativity for empowerment in communal economic resurgence.

\section{Limitation and Future Studies}

The study was limited to a full-scale impact assessment of coronaviruses and its continuous spread to the sub-region, especially as no permanent cure for curbing the disease is yet to be established. Further studies should be conducted to identify a complete solution to curb this pandemic.

\section{Funding}

Authors did not receive any funding from any individual or institutions for this study.

\section{Conflicts of Interest}

The authors declare no conflicts of interest regarding the publication of this paper.

\section{References}

Abinraj, R. S. (2020). Coronavirus: The World Economy at Risk. https://www.researchgate.net/publication/340116317

African Economic Outlook 2021 (2020). https://www.afdb.org/en/knowledge/publications/african-economic-outlook

Ahmad, S., Hafeez, A., Siddqui, S. A., Ahmad, M., \& Mishra, S. (2020). A Review of COVID-19 (Coronavirus Disease-2019) Diagnosis, Treatments and Prevention. EJMO, 4, 116-125. https://doi.org/10.14744/ejmo.2020.90853

Ahmed, S. S. (2020). The Coronavirus Disease 2019 (COVID-19): A Review. Journal of Advances in Medicine and Medical Research (JAMMR), 32, 1-9. https://doi.org/10.9734/jammr/2020/v32i430393

Aiello, A. E., Murray, G. F., Perez, V., Coulborn, R. M., Davis, B. M., Uddin, M., Shay, D. K., Waterman, S. H., \& Monto, A. S. (2010). Mask Use, Hand Hygiene, and Seasonal Influenza-Like Illness among Young Adults: A Randomized Intervention Trial. The Journal of Infectious Diseases, 201, 491-498. https://doi.org/10.1086/650396

Amewu, S., Asante, S., Pauw, K., \& Thurlow, J. (2020). The Economic Costs of COVID-19 in Sub-Saharan Africa: Insights from a Simulation Exercise for Ghana. The European 
Journal of Development Research, 1-26. https://doi.org/10.1057/s41287-020-00332-6

Anele, U. (2020). Top 20 Fastest Growing Economies in Africa, 2020.

https://listwand.com/top-20-fastest-growing-economies-in-africa/

Asante, L. A., \& Mills, R. O. (2020). Exploring the Socio-Economic Impact of COVID-19 Pandemic in Market Places in Urban Ghana. African Spectrum, 55, 170-181. https://doi.org/10.1177/0002039720943612

Ayadi, R. et al. (2020). COVID-19 in the Mediterranean and Africa Diagnosis, Policy Responses, Preliminary Assessment and Way Forward. https://emnes.org/wp-content/uploads/2020/04/emea-emnes study-COVID-19 in the mediterranean and africa-1.pdf

Cheng, V. C. C., Tai, J. W. M., Wong, L. M. W., Chan, J. F. W., Li, I. W. S., To, K. K. W., Hung, I. F. N., Chan, K. H., Ho, P. L., \& Yuen, K. Y. (2010). Prevention of Nosocomial Transmission of Swine-Origin Pandemic Influenza Virus A/H1N1 by Infection Control Bundle. Journal of Hospital Infection, 74, 271-277.

https://doi.org/10.1016/j.jhin.2009.09.009

Cohen, J. (2020). Wuhan Seafood Market May Not Be Source of Novel Virus Spreading Globally. Science. https://doi.org/10.1126/science.abb0611

Davies, A., Thompson, K., Giri, K., Kafatos, G., Walker, J., \& Bennett, A. (2013). Testing the Efficacy of Homemade Masks: Would They Protect in an Influenza Pandemic? Disaster Medicine and Public Health Preparedness, 7, 413-418. https://doi.org/10.1017/dmp.2013.43

Dhama, K., Sharun, K., Tiwari, R., Sircar, S., Bhat, S., Malik, Y. S., Singh, K. P., Chaicumpa, W., Bonilla-Aldana, D. K., \& Rodriguez-Morales, A. J. (2020). Coronavirus Disease 2019-COVID-19. Clinical Microbiology Reviews, 33, e00028-20. https://doi.org/10.1128/CMR.00028-20

Dharmadhikari, A. S., Mphahlele, M., Stoltz, A., Venter, K., Mathebula, R., Masotla, T., Lubbe, W., Pagano, M., First, M., Jensen, P. A., Van Der Walt, M., \& Nardell, E. A. (2012). Surgical Face Masks Worn by Patients with Multidrug-Resistant Tuberculosis Impact on Infectivity of Air on a Hospital Ward. American Journal of Respiratory and Critical Care Medicine, 185, 1104-1109. https://doi.org/10.1164/rccm.201107-1190OC

Di Gennaro, F., Pizzol, D., Marotta, C., Antunes, M., Racalbuto, V., Veronese, N., \& Smith, L. (2020). Coronavirus Diseases (COVID-19) Current Status and Future Perspectives: A Narrative Review. International Journal of Environmental Research and Public Health, 17, 2690. https://doi.org/10.3390/ijerph17082690

ECDC (2020). COVID-19 Aviation Health and Safety Protocol. https://www.icao.int/MID/Documents/RPTF\%20Stream\%201/EASA\%20COVID-19\%2 0Aviation\%20HSProtocol\%20-\%20Guidance\%20airline\%20passengers-Pandemic.pdf

ECDC (2021). COVID-19 Situation Update Worldwide as at Week 3, 28 January 2021 by European Centre for Disease Prevention and Control (ECDC).

https://www.ecdc.europa.eu

https://www.ecdc.europa.eu/sites/default/files/documents/COVID-19-face-masks-com munity-first-update.pdf

Factcheckghana (2020). Key Highlights of the Impact of COVID-19 on Ghana's Econo$m y$.

https://www.fact-checkghana.com/key-highlights-of-the-impact-of-COVID-19-on-gha nas-economy/

Ganyani, T., Kremer, C., Chen, D., Torneri, A., Faes, C., Wallinga, J., \& Hens, N. (2020). Estimating the Generation Interval for Coronavirus Disease (COVID-19) Based on Symptom Onset Data, March 2020. Eurosurveillance, 25, Article ID: 2000257. 
https://doi.org/10.2807/1560-7917.ES.2020.25.17.2000257

Ghana Health Service (2020). https://ghanahealthservice.org/covid19/

Gorbalenya, A. E., Baker, S. C., Baric, R. S., de Groot, R. J., Drosten, C., Gulyaeva, A. A., Haagmans, B. L., Lauber, C., Leontovich, A. M., Neuman, B. W., Penzar, D., Perlman, S., Poon, L. L. M., Samborskiy, D., Sidorov, I. A., Sola, I., \& Ziebuhr, J. (2020). Severe Acute Respiratory Syndrome-Related Coronavirus: The Species and Its Viruses-A Statement of the Coronavirus Study Group. bioRxiv. https://doi.org/10.1101/2020.02.07.937862

Helmy, Y. A., Fawzy, M., Elaswad, A., Sobieh, A., Kenney, S. P., \& Shehata, A. A. (2020). The COVID-19 Pandemic: A Comprehensive Review of Taxonomy, Genetics, Epidemiology, Diagnosis, Treatment, and Control. Journal of Clinical Medicine, 9, 1225. https://doi.org/10.3390/jcm9041225

Huang, C., Wang, Y., Li, X., Ren, L., Zhao, J., Hu, Y., Zhang, L., Fan, G., Xu, J., Gu, X. et al. (2020). Clinical Features of Patients Infected with 2019 Novel Coronavirus in Wuhan, China. The Lancet, 395, 497-506. https://doi.org/10.1016/S0140-6736(20)30183-5

Hui, D. S., Azhar, E. I., Madani, T. A., Ntoumi, F., Kock, R., Dar, O., Ippolito, G., Mchugh, T. D., Memish, Z. A., Drosten, C., Zumla, A., \& Petersen, E. (2020). The Continuing 2019-nCoV Epidemic Threat of Novel Coronaviruses to Global Health-The Latest 2019 Novel Coronavirus Outbreak in Wuhan, China. International Journal of Infectious Diseases, 91, 264-266. https://doi.org/10.1016/j.ijid.2020.01.009

icsb.org (2020). Impact of the Coronavirus (COVID-19) on the African Economy. https://icsb.org/wp-content/uploads/2020/04/COVID-19-impact-on-African-economy. pdf.pdf.pdf.pdf

IMF (2020). World Economic Outlook Update (pp. 1-20).

Isihak, F. A., Hamad, M. A., \& Mustafa, N. G. (2020). COVID-19: An Updated Review. Russian Journal of Infection and Immunity = Infektsiya i immunitet, 10, 247-258. https://doi.org/10.15789/2220-7619-CAU-1443

Kumar, S. (2020). Economic Impact of COVID-19 and Challenges of Recovery. Integrated Risk of Pandemic: COVID-19 Impacts, Resilience and Recommendations.

Larbi-Odam, C., Ankomah, G., \& Lartey, Y. A. (2020). Economic Impact of the COVID-19 Pandemic on the Economy of Ghana.

https://www2.deloitte.com/gh/en/pages/about-deloitte/articles/economic-impact-of-C OVID-19-pandemic-on-the-economyof-ghana.html

Larson, E. L., Ferng, Y.-H., Wong-McLoughlin, J., Wang, S., Haber, M., \& Morse, S. S. (2010). Impact of Non-Pharmaceutical Interventions on URIs and Influenza in Crowded, Urban Households. Public Health Reports, 125, 178-191. https://doi.org/10.1177/003335491012500206

Lei, J., Kusov, Y., \& Hilgenfeld, R. (2018). Nsp3 of Coronaviruses: Structures and Functions of a Large Multi-Domain Protein. Antiviral Research, 149, 58-74. https://doi.org/10.1016/j.antiviral.2017.11.001

Leung, N. H. L., Chu, D. K. W., Shiu, E. Y. C., Chan, K.-H., McDevitt, J. J., Hau, B. J. P., Yen, H.-L., Li, Y., Ip, D. K. M., Peiris, J. S. M., Seto, W.-H., Leung, G. M., Milton, D. K., \& Cowling, B. J. (2020). Respiratory Virus Shedding in Exhaled Breath and Efficacy of Face Masks. Nature Medicine, 26, 676-680. https://doi.org/10.1038/s41591-020-0843-2

Li, J., You, Z., Wang, Q., Zhou, Z., Qiu, Y., Luo, R., \& Ge, X. (2020). The Epidemic of 2019-Novel-Coronavirus (2019-nCoV) Pneumonia and Insights for Emerging Infectious Diseases in the Future. Microbes and Infection, 22, 80-85.

https://doi.org/10.1016/j.micinf.2020.02.002 
Macintyre, C. R., Seale, H., Dung, T. C., Hien, N. T., Nga, P. T., Chughtai, A. A., Rahman, B., Dwyer, D. E., \& Wang, Q. (2015). A Cluster Randomised Trial of Cloth Masks Compared with Medical Masks in Healthcare Workers. BMJ Open, 5, e006577. https://doi.org/10.1136/bmjopen-2014-006577

Mahmud, S. (2020). Impact of Corona Virus on the Global Economy. https://www.researchgate.net/publication/339435164

Ministry of Finance and Economic Planning (2020). Mid-Year Review of the Budget Statement and Economic Policy of the Government of Ghana and Supplementary Estimate for the 2020 Financial year.

https://www.mofep.gov.gh/sites/default/files/budget-statements/2020-Mid-Year-Budge t-Statement v3.pdf

Ministry of Finance and Economic Planning (2021). 2021 Budget Statement and Economic Policy.

https://www.mofep.gov.gh/news-and-events/2021-budget-statement-and-economic-Po licy

Minnesota Department of Health (2020). Coronavirus Disease 2019 (COVID-19). https://www.health.state.mn.us/diseases/coronavirus/materials/basics.pdf

Modernghana (2020). https://www.modernghana.com/amp/news/990912/COVID-19-akufo-addo-lauds-3-yo ung-inventorsof.html

Mugisha, F. (2020). COVID-19: Socio-Economic Impact in Ghana. Briefing Note No. 1, $1-3$.

Naser, A. Y. et al. (2020). Mental Health Status of the General Population, Healthcare Professionals, and University Students during 2019 Coronavirus Disease Outbreak in Jordan: A Cross-Sectional Study. Brain and Behavior, 10, e01730. https://www.medrxiv.org/content/10.1101/2020.04.09.20056374v1

National Institute for Occupational Safety and Health (NIOSH) (2018). Use of Respirators and Surgical Masks for Protection against Healthcare Hazards. Atlanta, GA: CDC. https://www.cdc.gov/niosh/topics/healthcarehsps/respiratory.html

Nishiura, H., Linton, N. M., \& Akhmetzhanov, A. R. (2020). Serial Interval of Novel Coronavirus (COVID-19) Infections. International Journal of Infectious Diseases, 93, 284-286. https://doi.org/10.1016/j.ijid.2020.02.060

Njugunah, M. (2020). East Africa: Region Maintains Lead as Continent's Fastest Growing Region at 5\%. https://allafrica.com/stories/202002040220.html

OECD (2020). COVID-19 and the Aviation Industry: Impact and Policy Responses. https://www.oecd.org/coronavirus/policy-responses/COVID-19-and-the-aviation-indu stry-impact-and-policy-responses-26d521c1/

Ofori-Atta, K. (2020). Economic Impact of the COVID-19 Pandemic on the Economy of Ghana. Statement to the Parliament of Ghana. https://www.mofep.gov.gh https://www.mofep.gov.gh/sites/default/files/news/MoF-Statement-to-Parliament 202 00330.pdf

Ong, S. W. X., Tan, Y. K., Chia, P. Y., Lee, T. H., Ng, O. T., Wong, M. S. Y., \& Marimuthu, K. (2020). Air, Surface Environmental, and Personal Protective Equipment Contamination by Severe Acute Respiratory Syndrome Coronavirus 2 (SARS-CoV-2) from a Symptomatic Patient. JAMA, 323, 1610-1612. https://doi.org/10.1001/jama.2020.3227

Ozili, P., \& Arun, T. (2020). Spillover of COVID-19: Impact on the Global Economy. SRN Electronic Journal, 1-6. https://doi.org/10.2139/ssrn.3562570

Parolin, M., Parisotto, M., Zanchetta, F., Sartorato, P., \& Menis, D. E. (2020). Coronavi- 
ruses and Endocrine System: A Systematic Review on Evidences and Shadows. Endocrine, Metabolic \& Immune Disorders-Drug Targets, ahead of print.

https://pubmed.ncbi.nlm.nih.gov/32888287/

https://doi.org/10.2174/1871530320666200905123332

PwC (2020). COVID-19 and Its Impact on Ghanaian Banking Industry: Counting the Cost.

https://www.pwc.com/gh/en/assets/pdf/COVID-19-and-its-impact-on-the-ghanaian-b anking-industry.pdf

Qu, L. J., Li, J. C., \& Ren, H. (2020). COVID-19: The Epidemiology and Treatment. British Journal of Hospital Medicine, 81, 1-9. https://doi.org/10.12968/hmed.2020.0580

Rengasamy, S., Eimer, B., \& Shaffer, R. E. (2010). Simple Respiratory Protection-Evaluation of the Filtration Performance of Cloth Masks and Common Fabric Materials against 20 - 1000 nm Size Particles. Annals of Occupational Hygiene, 54, 789-798.

Rothe, C., Schunk, M., Sothmann, P., Bretzel, G., Froeschl, G., Wallrauch, C., Zimmer, T., Thiel, V., Janke, C., Guggemos, W., Seilmaier, M., Drosten, C., Vollmar, P., Zwirglmaier, K., Zange, S., Wölfel, R., \& Hoelscher, M. (2020). Transmission of 2019-nCoV Infection from an Asymptomatic Contact in Germany. The New England Journal of Medicine, 382, 970-971. https://doi.org/10.1056/NEJMc2001468

Sengbeh, K. D. (2020). Liberia: The Looming Danger beyond the Use of the Face Masks -Let's Take Action Now. https://allafrica.com/stores/202004290448.html

Snyder, H. (2019). Literature Review as a Research Methodology: Overview and Guidelines. Journal of Business Research, 104, 333-339.

https://www.elsevier.com/locate/jbusres

https://doi.org/10.1016/j.jbusres.2019.07.039

Soewarno (2020). Understanding New Type of Corona Virus Infecting Thousands of People.

https://unair.ac.id/site/article/read/2804/understanding-new-type-of-corona-virus-infe cting-thousands-of-people.html

The Zimbabwe Independent (2020). COVID-19: Africa to Lose US\$270 Billion in EXports. https://www.theindependent.co.zw/2020/04/10/COVID-19-africa-to-lose-us270-billion -in-exports/

To, K. K., Tak, O., Tsang, Y., Leung, W., Tam, A. R., Wu, T., Lung, D. C., Yip, C. C., Cai, J., Chan, J. M., Chik, T. S., Lau, D. P., Choi, C. Y., Chen, L., Chan, W., Chan, K., Ip, J. D., Ng, A. C., Poon, R. W. et al. (2020). Temporal Profiles of Viral Load in Posteriororopharyngeal Saliva Samples and Serum Antibody Responses during Infection by SARS-CoV-2: An Observational Cohort Study. The Lancet Infectious Diseases, 20, 565-574. https://doi.org/10.1016/S1473-3099(20)30196-1

Tralac's Daily News Selection (2020). https://www.tralac.org/news/article/14688-tralac-s-daily-news-selection-wednesday-24 -june-2020.html

Unhale, S. S., Ansar, Q. B., Sanap, S., Thakhre, S., Wadatkar, S., Bairagi, R., Sagrule, S., \& Biyani, K. R. (2020). A Review on Corona Virus (COVID-19). World Journal of Pharmaceutical and Life Sciences, 6, 109-115.

Version 10 (2020). COVID-19 Quick Reference Guidelines. https://covid19.health.gov.mv/wp-content/uploads/2020/07/COVID-19-QR-SOPs-v10. pdf

Wang, D., Hu, B., Hu, C., Zhu, F., Liu, X., Zhang, J., Wang, B., Xiang, H., Cheng, Z., Xiong, Y., Zhao, Y., Li, Y., Wang, X., \& Peng, Z. (2020). Clinical Characteristics of 138 
Hospitalized Patients with 2019 Novel Coronavirus-Infected Pneumonia in Wuhan, China. JAMA, 32, 1061-1069. https://doi.org/10.1001/jama.2020.1585

Wei, W. E., Li, Z., Chiew, C. J., Yong, S. E., Toh, M. P., \& Lee, V. J. (2020). Presymptomatic Transmission of SARS-CoV-2-Singapore, January 23-March 16, 2020. Morbidity and Mortality Weekly Report, 69, 411-415. https://doi.org/10.15585/mmwr.mm6914e1

Wong, G., Greenhalgh, T., Westhorp, G., Buckingham, J., \& Pawson, R. (2013). RAMESES Publication Standards: Meta-Narrative Reviews. BMC Medicine, 11, Article No. 20. https://doi.org/10.1186/1741-7015-11-20

World Health Organization (WHO) (2019). Non-Pharmaceutical Public Health Measures for Mitigating the Risk and Impact of Epidemic and Pandemic Influenza. Geneva: WHO.

https://apps.who.int/iris/bitstream/handle/10665/329438/9789241516839-eng.pdf

World Health Organization (WHO) (2020a). Coronavirus Disease (COVID-19) Weekly Epidemiological Update and Weekly Operational Update.

https://www.who.int/emergencies/diseases/novel-coronavirus-2019/situation-reports/

World Health Organization (WHO) (2020b). Getting Your Workplace Ready for COVID-19. https://www.who.int/docs/default-source/coronaviruse/getting-workplace-ready-for-C OVID-19.pdf

Yu, W., Tang, G., Zhang, L., \& Corlett, R. T. (2020). Decoding the Evolution and Transmissions of the Novel Pneumonia Coronavirus (SARS-CoV-2/HCoV-19) Using Whole Genomic Data. Zoological Research, 41, 247-257.

https://doi.org/10.24272/j.issn.2095-8137.2020.022

Zhou, P., Yang, X., Wang, X., Hu, B., Zhang, L., Zhang, W., Guo, H., Jiang, R., Liu, M., Chen, Y., Shen, X., Wang, X., Zhan, F., Wang, Y., Xiao, G., \& Shi, Z. (2020). A Pneumonia Outbreak Associated with a New Coronavirus of Probable Bat Origin. Nature, 579, 270-273. https://doi.org/10.1038/s41586-020-2012-7

Zhu, N., Zhang, D., Wang, W., Li, X., Yang, B., Song, J., Zhao, X., Huang, B., Shi, W., Lu, R., Niu, P., Zhan, F., Ma, X., Wang, D., Xu, W., Wu, G., Gao, G. F., \& Tan, W. (2020). A Novel Coronavirus from Patients with Pneumonia in China, 2019. The New England Journal of Medicine, 382, 727-733. https://doi.org/10.1056/NEJMoa2001017

Zou, L., Ruan, F., Huang, M., Liang, L., Huang, H., Hong, Z., Yu, J., Kang, M., Song, Y., Xia, J., Guo, Q., Song, T., He, J., Yen, H.-L., Peiris, M., \& Wu, J. (2020). SARS-CoV-2 Viral Load in Upper Respiratory Specimens of Infected Patients. The New England Journal of Medicine, 382, 1177-1179. https://doi.org/10.1056/NEJMc2001737 